International Journal of Applied Linguistics \& English Literature

ISSN 2200-3592 (Print), ISSN 2200-3452 (Online)

Vol. 1 No. 4; September 2012

\title{
Audio Journal in an ELT Context
}

\author{
Neşe Aysin Siyli (Corresponding author) \\ School of Foreign Languages, Anadolu University \\ 26000 Eskişehir, Turkey \\ Tel: +90-222 3350580-6164Ｅ-mail: nasiyli@anadolu.edu.tr
}

Dr. Hüseyin Kafes

School of Foreign Languages, Anadolu University

26000 Eskişehir, Turkey

Tel: +90-222 3350580-6187Ｅ-mail: hkafes@gmail.com

Received: 15-06- 2012

doi:10.7575/ijalel.v.1n.4p.66
Accepted: 13-07- 2012

Published: 01-09- 2012

"Speech generally vanishes in the moment it is uttered, in an oral journal; however, this is not the case".

(Henry, 1994).

\begin{abstract}
It is widely acknowledged that one of the most serious problems students of English as a foreign language face is their deprivation of practicing the language outside the classroom. Generally, the classroom is the sole environment where they can practice English, which by its nature does not provide rich setting to help students develop their competence by putting the language into practice. Motivated by this need, this descriptive study investigated the impact of audio dialog journals on students' speaking skills. It also aimed to gain insights into students' and teacher's opinions on keeping audio dialog journals outside the class. The data of the study developed from student and teacher audio dialog journals, student written feedbacks, interviews held with the students, and teacher observations. The descriptive analysis of the data revealed that audio dialog journals served a number of functions ranging from cognitive to linguistic, from pedagogical to psychological, and social. The findings and pedagogical implications of the study are discussed in detail.
\end{abstract}

Key words: audio dialog journal, speaking skills, and student-teacher communication

\section{Introduction}

A prevailing problem the great majority of foreign language learners face in Turkey, as in many other countless countries, is having very little or no opportunity to practice the language they learn outside the classroom. For the most part, foreign language learners can practice speaking predominantly in the classroom with their classmates and teachers, which is by no means adequate considering the limited course hours allocated, the number of students, the limitations of the teacher, and the restrictions of the classrooms. Apart from restricting foreign language use within the classroom walls, making the language itself a study focus activity rather than for a real communicative purpose, this situation deprives students from developing competence as claimed by the proponents of the Output Hypothesis (Harley, 1993). Peyton (20009 also underlines the gravity of the same issue from teachers' perspective saying that although teachers often wish they had more time to communicate with their students, to learn about their backgrounds, interest and needs, to share information, and to follow their learning, they cannot do so because of time limitations. Driven by this reality, various solutions have been proposed over the years. One of these solutions is audiotaped/audio dialog journal, which, according to Brown, Garver, and Sagers (1996) alleviates this problem. According to Peyton (2000), dialog journals, which not only open a new channel of communication, but also provide another context for language development. Dialog 
journals also allow teachers to extend contact time with students and help teachers create optimal language learning conditions.

\subsection{Audio dialog journals in ELT}

Dialog journals have been implemented successfully in different contexts from elementary school to graduate school in a variety of subjects in various ways (Bode, 1989; Danielson, 1988; Gordon and MacInnis, 1993; Kirk, 1989; Peyton, 1988; Peyton and Staton, 1993; Peyton, Staton, Richardson, and Wolfram, 1993; Staton, 1980; Wang, 1996). One of these contexts is foreign language class. In addition to serving as a means of meaningful and genuine communication in a real-life like contextualized manner, it also presents language learners ample opportunities to develop their writing fluency. The idea of fostering a continuing exchange of ideas between teacher and student seems to be harmonious with Vygotsky's view on the role of language and social interaction in learning (Vygotsky, 1978; Gavelek, 1986; Gallimore and Tharp, 1990).

Unlike most of the present extensions of traditional activities, journal writing foregrounds the content, putting the form in the background. In this message-oriented communication, journal writers can express their ideas, thoughts, emotions, and feelings in their journal entries to communicate regularly with people of their choice such as their peers or teachers. What sounds even more remarkable is the fact that they can do so ignoring their ever-haunting ghost: fear of making mistakes. In addition to providing learners with content-wise freedom of self-expression in a relaxing atmosphere, it also allows learners to do so comfortably at their own pace, paying no heed to linguistic issues such as grammatical and lexical accuracy and syntactic complexity. Although the following excerpts describe written dialogue journal, almost all of its features, as claimed by Henry (1994), are also legitimate for audio dialog journals. As is underlined in the following excerpts, dialogue journals are not only an effective tool for use in developing communication and language skills in almost any student population, they are also a valuable way for teachers to connect with their students on a personal level. Staton describes dialog journals as:

"A dialogue journal contains a genuine conversation, written rather than spoken, a means by which individual students at any age can carry on a private discussion with their teacher. The interactive format of equal turns on the same topics is quite different from the traditional student personal journals, in which a teacher may sometimes make some kind of marginal comment on a student's entry, but only days or weeks after the student wrote it. The distinguishing characteristics of dialogue journals are their interactive, functional nature, and the creation of mutually interesting topics. Such dialogues occur on a daily or regular basis throughout the school year, extending the conversation across time for purposes of communication, self-understanding, negotiation of the classroom relationship, and problem solving. In the elementary school classroom, this simple, teacher-developed practice also involves meaningful, functional reading and writing as a single whole, just as speaking and listening are a seamless whole in oral discourse" (Staton, 1987: 49). (Italics added)

In addition to underlining similar benefits of dialog journals, Peyton and Reed (1990) underscore the freedom audio dialog journals offer to students saying:

"A dialogue journal, put very simply, is a conversation between a teacher and an individual student. However, this conversation differs from all others that they may have, in or out of the classroom; it is written, it is completely private, and it takes place regularly and continually throughout an entire school year or semester...Students write regularly in the journal, as much as they want and about whatever they choose, and the teacher writes back-not grading or correcting the writing, and not responding with simple platitudes or evaluative comments such as "Good" or "Interesting point!" The teacher is a partner in a conversation, who accepts what is written and responds as directly and openly as possible, while keeping in mind the student's language ability and interest" Peyton and Reed (1990:3-4). (Italics added)

As the italicized parts show, journals have a great therapeutic value as they provide students, especially the timid ones, with a means to express themselves. They also create opportunities for real communication with a real purpose, audience, and purpose (Peyton \& Reed, 1990). Another very important benefit of audio dialog journals is that they encourage students to express themselves freely without obsessing with form. Audio dialog journals also have benefits for teachers ranging from knowing students better as individuals and becoming more informed of student strengths and shortcomings to building rapport and trust with students (Peyton, 1988). In the same manner as a written dialogue journal, audio dialog journals serve many invaluable functions both for students and teachers, especially for students who have no other opportunity to practice speaking outside the classroom. Journals come in a variety of forms. For example, McGrath (1992) identifies three types of oral journals: the audiotape journal, the cassette notebook and the oral dialog journal. The audiotape journal was developed to 
increase students' fluency, to raise their awareness of pronunciation difficulties, to give them a chance to speak with a native English speaker, and to provide the teacher with more efficient use of time. The teacher's role is to speak about the topic, respond to the content, and comment on the pronunciation and grammar. The cassette notebook is similar to the audiotape journal, but is used to complete specific assignments related to a variety of language skills; such as practicing grammar or vocabulary covered in the class. The oral dialog journal bears an emphasis on student's discovering their identity within the new culture in which they are living, which means a class discussion leads to a journal topic which the student discusses on record (McGrath, 1992).

Apart from the above-cited benefits, audio dialog journal offers various benefits both to students and teachers such as:

- $\quad$ Providing increased opportunities for communication between students and teachers

- Allowing the teacher to individualize language and content learning,

- Allowing the teacher to gain information that can assist in lesson planning

- Enabling students to have the opportunity to use writing for genuine communication

- $\quad$ Providing students with an additional opportunity for reading

- $\quad$ Providing students with an additional opportunity for listening and speaking

- Offering an opportunity of speaking FL for the students who are anxious to talk in front of a class and build self-confidence

- Helping students reduce the anxiety of speaking FL

- Helping students reduce the anxiety of interacting with the teachers

- Helping students be more fluent and develop some strategies to speak more fluently

- Raising consciousness of the student's common pronunciation, grammar, structure and vocabulary mistakes

Peyton \& Reed (1990:3-4)

In addition to serving a unique form of communication of ideas, in the same approach as written dialog journals, audio dialog journals have been found useful (Egbert, 1992). In underlying the benefits of dialogue journals, Barkley et al. (2005) claim that dialogue journals "offer a formal medium for students to record their thoughts, connect coursework to their personal lives, and ask each other questions". They also argue that the effectiveness of the dialogue journal increases "when writers know that someone who is also interested in the topic will read and respond to their entries" (p.236). Several studies conducted on audio dialog journals have demonstrated the positive impact of them. For example, Brown et. al. (1996) found that audio dialog journals influenced students' feelings about their relationship with their teacher. Liao and Wong's study (2010) on the 'Effects of dialog journals on L2 students' writing fluency, reflections, anxiety, and motivation' has shown that dialog journals contributed to students' promoting their English writing proficiency, enhancing students' reflective awareness of English and promoting their self-growth as human beings. Also dialog journals were effective in reducing students' writing anxiety and increasing their motivation. Although numerous studies have been conducted on the benefits of written dialog journals, very few studies have focused on the benefits of audio/oral dialog journals. For example, Nama and Ramazanazdeh (2011) found that oral dialog journals helped increase Iranian EFL learners' communicative competence. They also demonstrated that oral dialog journals helped teachers know the students more and understand their communication problems. Marefat and Moladoust's study (2011) on audiotaped oral dialog journal and vocabulary acquisition and retention draws attention to similar benefits of audio dialog journals.

\subsection{Purpose of the study}

Although several studies have been conducted on the benefits of written dialog journals, few studies have been done investigating the benefits of audio dialog journals. With this lacuna to fill in, this study aims to investigate the benefits of audio dialog journal writing for students and teachers.

\section{Method}

\subsection{The setting and participants}

The study was conducted at Anadolu University, one of the leading universities in Turkey, in the fall semester of 2010-2011 academic years with the participation of 17 elementary level students from the School of Foreign Languages, which at the time offered skills-based instruction. The participants, aged between 17 and 20, were from the first researcher's listening and speaking classes. Four students from one class and thirteen from the 
other class initially volunteered for the study, but one did not hand in any recording and another one had attendance problem and quit school at the very beginning of the study. The following table presents information about the participants and their recordings and written feedback.

Table 1. The number of the participants, their recordings, and written feedback

\begin{tabular}{ccc}
\hline No. of the participants & No. of student recording & No. of student written feedback \\
\hline 3 & 1 & 1 \\
7 & 2 & 2 \\
4 & 3 & 3 \\
2 & 4 & 4 \\
1 & 4 & 3 \\
Total:17 & 14 & 13 \\
\hline
\end{tabular}

\subsection{Data collection instruments}

The data for the study were collected through participant recordings, participant written feedback on the recordings, interview with the participants, and teacher observation. The participants recorded their own speech on any issue they wished to speak about four times. The participants were not restricted in any way. They could make preparations for the recordings and talk about their area of interest as long as they wanted to. In addition to the recordings, they also gave written feedback on every entry, describing the process in detail in Turkish. As Turkish is their mother tongue and they had indicated they would feel more comfortable in giving written feedback in Turkish at the beginning of the study, they did so. A week after they handed in their recordings, the first writer (henceforth I) gave them feedback, focusing on the content, vocabulary, structure, and pronunciation. Another means of data collection was informal observation of the participants. At the end of the study, an unstructured interview regarding the pros and cons of the process with the participants was held.

\subsection{Data collection process}

\subsubsection{Teacher perspective}

Although the success of the speaking journals relies heavily on the quality of teacher responses (Ho, 2003), I hesitated at first to give feedback by recording my voice since it seemed to me that it would take a lot of time, but then I realized that there would be no use of it if the students did not get any recorded teacher response. Throughout the process, I adopted and followed the following principles. I responded fully to each and every entry rather than providing them with some brief comments in order to help students view that it was a real and meaningful forum of communication. As the main focus was on purposeful communication, I avoided giving feedback on language use as long as it did not interfere severely with communication, as long as it did not cause ambiguity, and as long as students did not request. Even in such instances, which were not very common, I preferred to deal with such problems by guiding and asking questions in my responses. I gave feedback on language use only when students insisted. Even in such cases, I tried to do so by reformulating the problematic language items, acting as a role model for them. As it was a new experience for me as well as for my students, I experienced some difficulties at first. It was very unnatural for me to hear my voice on the records, since I had not done such a thing before. For the first feedbacks, I re-recorded my voice until I acquired the usual tone. After several attempts, I got used to it and felt comfortable in recording my own voice. At first, it sounded very weird to address my students in their absence. When I first listened to their recordings, I took notes of the issues I wanted to comment on and the language use I wanted to reformulate. Strangely enough, I felt an inclination to focus on correcting language use at first, but as it would turn out to be a string of corrected versions of their utterances, I took notes of only the key language items that could cause communication breakdown to be reformulated. As it would be discourteous to interrupt students when they are speaking and overcorrection prevents them from concentrating on the message (Chastain, 1971), I remodeled the misused language items considering how general, frequent, comprehensible etc. they were based on the following categorization by Johansson (1973):

- Generality; mistakes on general rules are more important than isolated lexical items

- Frequency; errors with common words are more serious

- Comprehensibility; is the meaning lost? 
- Curriculum; has the feature been taught?

- Competence/performance; is it just a slip of a pen?

Some examples of what my reformulation mainly focused on;

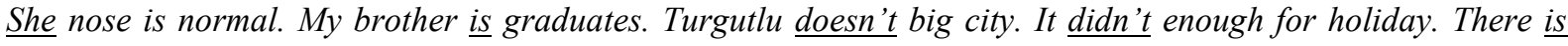
have carpet museum.

My father is slightly overwhite! ....science I lived there. Useful life standarts. I took ticket for tram. She has got tall and yellow hair. I'll slap (sleep)

All my childhood was lived in Aşgabat. I don't know how can I say.

I paid special attention to asking questions and commenting on the issues central to the entries to encourage students to elaborate on their upcoming entries. At the end of each response, I commented positively on the overall strengths of their entries to foster their self-confidence. Surprisingly, all of them had their own ways of dealing with my reformulation since some of them never used the reformulated structures or vocabulary items in upcoming entries, while some relied heavily on the reformulated language items. Yet some others made use of both.

At first, I planned to return the recordings every week, but it turned out to be impossible for me to record my entries the same week they handed in me theirs. As a result, I returned my responses a week after they handed me in their records. How long it would take me to record my responses was another important concern for me to consider. I worked on the entries for two hours for the first records and for the second and the third it nearly took one and half-hour. However, the last one took me thirty minutes since there were only five students left. I found it less tiring to start recording my responses by having a long break after listening to their recordings and taking notes of the important issues.

\subsubsection{Technical aspect}

It was very practical to use cell phones as a recording tool since all of my students had one and were very good at using it. One of my students had experienced a failure on her cell phone but she borrowed one of her friend's cell-phones. They sent their recordings through Bluetooth to my computer directly. When we had difficulties transferring the recordings into my computer, they sent them as voice-mails. In addition, during this study, we had a one-week holiday, which I thought would interrupt the motivation on the study and cause a pause in exchanging recordings. However, my students sent their recordings through voice-mails. The length of my students' recordings ranged from 30 seconds to 3 minutes and the file format was '.amr', while some of my students preferred 'windows media player' files. I listened to each record using 'QuickTime Player' and "Windows Media Player".

\section{Results and discussion}

\subsection{Student written feedback}

After each recording, most of my students gave me a written feedback. At the end of the study, I interviewed the participant to get their opinions and suggestions about the study. Two of my students sent their post-study feedbacks in writing as they were away. After each recording, I wanted my students to answer nine questions. They mostly preferred to answer the questions in their native language and they also expressed their opinions in words and phrases only in L2 at the beginning. However, in their last feedbacks, it seemed they were more willing to use L2 to express their views. That might be because they gained more confidence.

They were free to decide on their entry topics they would like to talk about, which would give them an opportunity to be autonomous. It seemed that many of them chose their topics from the subjects dealt with in the classes adding a personal dimension to them. For the first recording, many of them preferred to introduce their families since it was the beginning of the term and they just left their parents and we were studying "introducing someone" in the class. One of their entries sets off by:

"I miss them too much, that's why I wanted about them to talk".

There were two other students whose entry topics were similar; one chose to talk about himself:

"As a beginning, I thought that's very convenient" and his way of thinking showed me that he totally agreed that this study was a process and he created some steps to build a communication chain. Another student introduced her hometown, using mostly simple present tense and justified her preference saying that she knew the topic and 
the structure very well. Only one of my students, a repeat student, explained that he chose the topic because it was exciting. He seemed very confident and not afraid of making any mistakes. For the following recordings, they chose topics that had already been dealt with in the courses. Only once did one student ask me to assign her a topic. She explained that I, as a teacher, would know better which topics would be useful for them to focus on. This might have been because the exam was approaching and some of my students started to think that the project would be a good practice for their speaking exams.

The following questions focused on their feelings before, during, and after the recording processes:

1. What process did you go through in making your first recording?

2. What changed after the second and the third time?

3. What do you do when you listen to my response?

4. How much time do you spend on this activity?

5. How is this activity useful?

6. How could it be more useful?

(Henry, 1994, pp. 71, 74)

For the first recording, all of my students stated that they were very excited and stressful before recording their entries even though they had had chances to record their voice over and over again. Starting from the second recordings, it seemed that they began to get used to it and became more relaxed; yet some had difficulty in keeping calm when recording their voice. It was not until the third recording that they all stated they felt comfortable before recording. Their feelings for the pre and during recording stages were nearly the same. Some of their comments during the recording phase are:

"I always think that my teacher will listen to my voice and I feel afraid to make mistakes",

"I usually have a feeling that I'll mispronounce words",

"I am worried that I cannot talk long enough".

Nearly all of them stated that they felt fully relaxed when they finished working on the recording. It seemed to me that recording their voice or speaking English was a completely stressful activity for most of them. Some answers that led me to think so were:

"I thought myself that such a crazy man I am!"

Another student underlined that she had empathy with me saying

"When I finished, I listened to my entry and thought my voice is so bad and I hesitated a lot!"

I also asked my students what preparations they had made before recordings. Most of them preferred to get prepared for recordings by writing: they wrote down and/or took notes of what they would say and revise it many times before making the final version of the recording. The stimulus behind choosing topics they were already familiar with was that they were both anxious about the coherence of their speech and they wanted to be fluent. Only one of my students stated that he tried to motivate himself making some listening activities and tried to focus on what to do next. Another one explained that he looked for some vocabulary. The interesting point about this student is that he looked just for the meaning of the word, not its pronunciation although he was an elementary level student.

With regards to the feelings and problems they faced during the process, four of my students stated that for the first recording, they had occasional hesitations, sometimes because they could not find the right vocabulary and sometimes they forgot what to say next. Many of them had difficulties with vocabulary even if they had made preparations before the recording. They stated that during the recording, they wanted to say something other than what they had previously prepared, but since they did not have sufficient vocabulary, they felt they could not project what they really thought. In addition to language-related problems, some had other problems. Two of them said that they had trouble in finding a quiet place to record their voice. Since many of them stayed in dormitories and shared their rooms with at least two roommates, they faced location-related problems. For example, one of them explained that she felt very shy to speak English in front of her roommates. In addition, one of my students stated that he was really surprised when he listened to his own voice and felt as if he had listened to someone else's voice on the record.

The length of time they spent on recording their entries ranged from 2 hours maximum to 10 minutes. Individual differences, level of anxiety, experience in prep school, and the importance attached to the study seemed to have a great effect on the length of time they spent on this project. Along the way, every student gradually spent less 
time on preparation. Many of them stated that they recorded their voice for more than five times for the first recording, while all of them had fewer re-recordings for the following recordings. However, one of them stated that although she showed great progress on re-recording times, at a particular stage, she felt tired and unmotivated, so she re-recorded her voice more than she did the first time.

Apart from the difficulties and problems peculiar to recordings, we experienced communication breakdowns from time to time. The most important instance occurred when one of my students did not even realize that my recordings was a response to her entry, as I focused more on reformulating the language items she had used wrongly. As she did not inform me about this misunderstanding on time, we realized this miscommunication in the interview given at the end of the study. Yet in another case, one of them talked about something totally different as he misunderstood my questions.

\subsection{Interview}

The following are the questions addressed to the participants and their responses collected during the interview held with the five randomly chosen students, who regularly handed in their journal entries.

1. Are you doing anything differently now-and has the process you used with your speaking journal changed? All of the responses underlined that students did less and less writing in time. Though they prepared for the recording by noting down full sentences at first, with every audio journal entry, preparation with full sentences left its place to taking notes in phrases and words. The same decline in preparation was seen in the number of recordings done in that their preparations had fewer recordings towards the last entries. They rationalized this decline stating that they were very excited at the beginning, but as time went by, they were able to sound natural. What is more, they could add their ideas spontaneously in the last two recordings.

2. What have you learnt in keeping an oral journal?

The participants' responses centered mostly on pronunciation, language use, and fluency gains. They underlined that they were happy with their recordings after numerous recordings based on 'interesting and interactive feedback they received,' (in their own words) and feedback received face-to-face from the teacher.

3. What would you do differently if you could do it again?

The responses received underlined the reality that the process has contributed positively to the participants since they gave considerable thought on what and how differently they would like to do audio journal if they had to do so. Their responses focused predominantly on the topic. While some would choose current topics from daily news, some others would opt to talk on topics totally different from the ones discussed in the classes. In addition to this personal point, they also gave consideration to the interactional dimension stating that they would have more interaction with their peers. One participant also expressed her wish to interact more with the teacher.

4. What attracts your attention the most when you consider your last two recordings?

All of the participants highlighted their improvement in pronunciation and fluency. They stated that the duration of their speech increased and that they became comfortable in doing so.

5. Have you ever deleted or re-recorded?

As they underlined their multiple recordings in response to question 2 above, all of them except for one stated that they had deleted and made recordings again and again until they were happy with the final production.

6. How does it help to listen to your own voice?

One of the participants stated that he had never listened to his recording, so he had no idea about it. On the other hand, the others stressed that at first listening to their own voice was somehow different and a completely novel experience. They were foreign to their own voices like many others put in the same situation. In addition to personal awareness, they also made linguistic gains by recognizing their own mistakes and learning from them.

7. Have you picked up on any error correction?

The central idea of the responses centered on using the language grammatically. The participants highlighted the fact that they made grammatical mistakes in their first recording attempts. Surprisingly, one of the participants drew attention to a causal relationship between her anxiety and her grammatical mistakes, stressing that her recording-wise anxiety was the main cause of her grammatical mistakes. However, in their subsequent attempts, they realized their mistakes and learned from them.

8. As a dictation, is it more useful to write before or after the recordings? 
International Journal of Applied Linguistics \& English Literature

ISSN 2200-3592 (Print), ISSN 2200-3452 (Online)

Vol. 1 No. 4; September 2012

All of the participants, with no exception, acknowledged that it was much more useful to write as a way of getting prepared for the recording. They also stated that this helped increase their fluency.

9. Which of these elements are most important to you in your speaking journal;

Communicating ideas, error correction, fluency, grammar, listening, pronunciation, or student initiative?

All of the participants found audio journal practice as a totally student centered activity, lending numerous opportunities to practice English. In underlining the significance of this practice, one of the participants stated that they could feel as teachers during the study and learned to critique themselves. The same student maintained; "It is better to criticize oneself rather than the teacher doing so". Unlike their total agreement on some of the previous questions, they had different priorities on this question. However, pronunciation, fluency, and anxiety were foregrounded, followed by grammar. This interesting observation underlines the reality that they attach much more importance to the way they convey their message than the message itself. While this could be due to their prior language learning experience, it could also be a signal that their affective filters were up, which coincides with their anxiety.

10. What would you say in preparing a speaking journal with a non-native speaker? Would you prefer a native speaker?

While all of the participants stated that they prefer a non-native teacher in this kind of a study, only one participant underlined the benefits of being involved with a native speaker teacher. He stated that it could be more beneficial in terms of pronunciation and intonation.

11. After having experienced speaking journals as a student, would you use them as a teacher, if you had to do so?

Despite agreeing on the interactive, interesting, and satisfactory features of audio dialog journals, most of the participants stated that more recordings and teacher feedback would be much better. They also highlighted that they would prefer face-to-face interviews with the teacher after each recording to get comprehensive feedback on common mistakes.

\subsection{Teacher observation}

As has been underlined so far, the participants have benefited a lot from the Audio Journal application in a variety of ways. When it comes to teacher's dimension, this useful practice has its own pros and cons. For one thing, it is very enjoyable for the teacher because of the friendly atmosphere it provides. This pleasant context enabled the teacher to get to know the students much better and allowed the teacher to be aware of the individual differences a lot more when compared to the usual classroom atmosphere. The teacher's cognizance of the individual differences of the participants provided the teacher with the opportunity to answer their personal needs. Unfortunately, from another standpoint, this application has some downsides. One of these is that it is time-consuming and tiring for the teacher, as it demands a lot from the teacher. It requires a lot of sacrifice and devotion from the teacher considering the heavy workload of teachers. Besides this physical dimension, it also has an important psychological issue. Sometimes, it is too demanding to motivate and encourage the participants not to lose track of the continuous process of recordings. Therefore, it looks logical to pre-determine some areas of focus for teacher feedback such as fluency. Also, it seems that this kind of a study, which demands a lot from the teacher, could better be conducted with smaller groups. Despite its cons for the teacher, Audio Journal is worth trying keeping in mind its benefits for students. As the saying goes, "If there is a will, there is a way", willingness is the key both for the participants and the teacher.

\section{Conclusion}

Considering the limited opportunity students of English as a foreign language have in practicing speaking English outside the classroom walls, we could say that audio dialog journals, with their promising nature, could be a solution. In addition to providing learners with freedom and ample opportunities to develop their competence through practicing speaking, it allows student to use their language for a real purpose in a meaningful context. This fully learner-centered practice strengthens communication and enhances relationship between students and teachers. During this meaningful communication process, students get fully involved in the process cognitively, psychologically, and linguistically. The individualized attention students get during this practice helps increase their confidence, as it is entirely a student initiative. They can also take full responsibility for identifying, pursuing, and working their goals. Besides, it gives a great chance to students to gain insight into their own learning styles and help them develop learning strategies. In the meantime, students could also gain knowledge and awareness of oral and aural aspects of their language; they can be aware of their own voices. 
International Journal of Applied Linguistics \& English Literature

ISSN 2200-3592 (Print), ISSN 2200-3452 (Online)

Vol. 1 No. 4; September 2012

Besides its direct positive impact on students, it also helps teachers build a special channel of communication and interaction with their students.

Our experience with audio dialog journals has been rewarding to both the students and to us personally. As very few tools in the teachers' toolbox seem to offer so much in one package, audio dialog journals seem to remain a mainstay in EFL classes. As argued by Avoseh (2005), Nama and Ramazanzadeh (2011), Marefat and Moladoust (2011), audio dialog journals could be successfully employed in ELT settings with students with no or limited opportunity to practice speaking outside the classroom.

Despite giving useful insight into the benefits of audio journal in an EFL context, it must be underlined that the findings of this descriptive study can by no means be generalized due to the limitations of the study. It is apparently clear that much more data from more learners at different levels of English proficiency are needed to generalize the findings.

\section{References}

Avoseh, M. B. M. (2005). The power of voice: Analysis of dialogue as a method in both elementary and adult education. International Journal of Case Method Research \& Application, XVII, 3, 1554-7752.

Barkley, E.F. Cross, K.P, \& Major, C.H. (2005). Collaborative Learning Techniques. A handbook for College Faculty. San Francisco: John Wiley \& Sons, Inc.

Bode, B. (1989). Dialogue journal writing. The Reading Teacher, 42, 568-571.

Brown, C., Garver, P., and Sagers, S. (1996). Audiotaped dialog journals. Paper presented at the annual meeting of Teachers of English to speakers of other languages. Chicago, IL, March 26-30.

Chastain, K. (1971). The development of modern language skills: Theory to Practice. Philadelphia: Center for Curriculum Development.

Danielson, K.E. (1988). Dialogue journals: Writing as conversation. Bloomington, IN: Phi Delta Kappa.

Egbert, J. (1992). Talk to me: An exploratory study of audiotaped journals. Journal of Intensive English Studies, 6:91-100.

Gallimore, R., \& Tharp, R. (1990). Teaching mind in society: Teaching, schooling, and literate discourse. In L.C. Moll (Ed.), Vygotsky and education: Instructional implications and applications of socio-historical psychology (175-205). Cambridge, UK: Cambridge University Press.

Gavelek, J.R. (1986). The social contexts of literacy and schooling: A developmental perspective. In T.E. Raphael (Ed.), The contexts of school-based literacy (pp. 3-26). New York: Random House.

Gordon, C.J., \& MacInnis, D. (1993). Using journals as a window on students' thinking in mathematics. Language Arts, 70, 37-43.

Harley, B. (1993). Instructional strategies and SLA in early French immersion. Studies in Second Language Acquisition, 15, 245-260. http://dx.doi.org/10.1017/S0272263100011980

Henry, L.M. (1994). Oral dialog journals; A Learner-centered Approach. Master's Thesis, University of Kansas.

Ho, Y. (2003). Audio-taped journals: an alternative form of speaking practice. ELT Journal, vol. 57/3, July. http://dx.doi.org/10.1111/j.1540-4781.1986.tb05256.x

Johansson, S. (1973). The identification and evaluation of errors of foreign languages: A Functional Approach. In Errata: Papers in Error Analysis, Jan Svartvik, ed. Lund, Sweden.

Kirk, B.V. (1989). Dialogue journals: A technique to strengthen ethnic pride and achievement. Journal of American Indian Education, 29(1), 19-25.

Liao, Ming-Tzu and Wong, Chia-Tzu (2010). Effects of dialog journals on L2 students' writing fluency, reflections, anxiety, and motivation. Reflections on English Language Teaching, Vol. 9, No. 2, pp. 139-170.

McGrath, M.M. (1992). Writing before speaking: How the Dialog Journal Stimulates Conversation. Master's Thesis, Biola University. 
International Journal of Applied Linguistics \& English Literature

ISSN 2200-3592 (Print), ISSN 2200-3452 (Online)

Vol. 1 No. 4; September 2012

Marefat, F. \&Moladoust, E. (2011). Audiotaped oral dialogue journal and vocabulary acquisition and retention. International Conference on Languages, Literature and Linguistics IPEDR, vol.26 IACSIT Press, Singapore.

Nama, E. S. \&Ramazanzadeh, A. (2011). The Effect of Oral Dialogue Journals on Iranian EFL Learners' Communicative Competence. Journal of English Language Teaching and Learning, 222, 53/Autumn-Winter, 161-182.

Peyton, J.K. (1988). Dialogue writing — Bridge from talk to essay. In J. Staton, R.W. Shuy, J.K. Peyton, \& L. Reed (Eds.), Dialogue journal communication: Classroom, linguistic, social, and cognitive views (pp. 88-106). Norwood, NJ: Ablex.

Peyton, J.K. (2000). Dialog journals: Interactive writing to develop language and literacy. National Center for ESL Literacy Education.

Peyton, J.K. \& Reed. L. (1990). Dialogue journal writing with nonnative English speakers: A handbook for Teachers. Alexandria, VA:TESOL.

Peyton, J.K., \& Staton, J. (Eds.). (1993). Dialogue journals in the multilingual classroom: Building language fluency and writing skills through written interaction. Norwood, NJ: Ablex.

Peyton, J.K., Staton, J., Richardson, G., \& Wolfram, W. (1993). The influence of writing task on ESL students' written production. In J.K. Peyton \& J. Staton (Eds.), Dialogue journals in the multilingual classroom: Building language fluency and writing skills through written interaction (pp. 196-221). Norwood, NJ: Ablex.

Staton, J. (1980). Writing and counseling: Using a dialogue journal. Language Arts, 57, 514- 518.

Staton, J. (1987). The Power of Responding in Dialogue Journals. The Journal Book. Ed. Toby Fulwiler. New Hampshire: Boynton/Cook Publishers, 1987. 47-63.

Vygotsky, L. (1978). Mind in society: The development of higher psychological processes. Cambridge, MA: Harvard University.

Wang, Y. (1996). E-mail dialogue journaling in an ESL reading and writing classroom. In: Proceedings of Selected Research and Development Presentations at the 1996 National Convention of the Association for Educational Communication and Technology, (18th, Indianapolis, IN). 